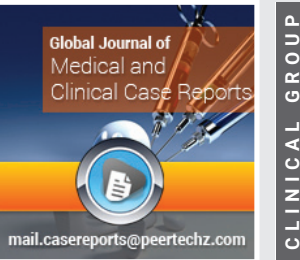

\title{
Diffuse oligosymptomatic Caroli's disease: Case report
}

\author{
Lemfadli $\mathbf{Y}^{1 *}$, Bouchrit $\mathbf{S}^{1}$, Fatimezzhara Lairani ${ }^{1}$, Ait Errami \\ $A^{1}$, Oubaha $S^{2}$, Samlani $Z^{1}$ and Krati $K^{1}$ \\ ${ }^{1}$ Gastroenterology Department, Mohammed VI University Hospital, Marrakech, Morocco \\ ${ }^{2}$ Physiology Department, Faculty of Medicine and Pharmacy at Cadi Ayyad University, Marrakech, \\ Morocco
}

Received: 02 July, 2020

Accepted: 08 July, 2020

Published: 09 July, 2020

*Corresponding author: Yassine Lemfadli, Department of Gastroenterology, Mohammed VI University Hospital, Marrakech 2360, Morocco,

E-mail: yassinelemfadli@gmail.com

Keywords: Caroli disease; Caroli syndrome; Congenital bile duct dilatation

https://www. peertechz.com

\section{Check for updates}

\section{Abstract}

This article describes a case of Caroli's disease in a 53-year-old female patient who complained non-specific abdominal pain without cholestasis or cholangitis. Ultrasound and hepatic magnetic resonance imaging showed segmental saccular dilations connected to intrahepatic bile ducts without hepatic fibrosis. This clinical case shows the possibility of having oligosymptomatic forms in the diffuse forms of Caroli disease, therefore the interest to consider this diagnosis in case of non-specific abdominal signs and to request a hepatic ultrasound.

\section{Introduction}

Caroli's Disease (CD) is a rare congenital disease, first described in 1958 by Jacques Caroli [1]. It is part of the spectrum of fibropolycystic liver pathologies. It is characterized by congenital non-obstructive dilation of the intrahepatic bile ducts. It can be localized or diffuse. Caroli syndrome is defined as its association with congenital hepatic fibrosis [2]. It is most often revealed by recurrent episodes of cholangitis [3].

This article describes the case of $\mathrm{CD}$ in a 53-year-old female patient with cystic formations distributed throughout the hepatic parenchyma, fortuitously diagnosed in adulthood, during the etiological investigation of non-specific abdominal pain.

\section{Case report}

A 53-year-old femal patient was seen in consultation. She complained of abdominal pain, which had started a year ago. The intensity of the pain was mild to moderate, intermittent, recurrent, located in the upper right quadrant and relieved by taking first-level pain relievers. The patient also reported urinary burns, but no fever or chills. She did not report jaundice, pruritus, vomiting, or weight loss.

The patient had no history of personal or family hepatopathy. She was taking no treatment and no toxic habits.
The clinical examination, in particular the abdominal, respiratory and cardiovascular examination, did not show any abnormalities. There was no jaundice or fever. The abdominal examination did not show hepatomegaly or signs of hepatocellular insufficiency or portal hypertension.

Hematological and biochemical examinations were normal (Table 1). There was no cholestasis or cytolysis. The levels of alpha-foeto-protein and carcinoembryonic antigen were normal. The cytobacteriological examination of the urine was sterile.

Abdominal ultrasound showed cystic formations throughout the hepatic parenchyma which seem to communicate with the intrahepatic bile ducts. There is no calculus or liver nodule. Magnetic Resonance Imaging (MRI) (Figure 1) confirmed the diagnosis of $\mathrm{CD}$. The liver was of normal size, with regular contours with the presence of multiple cystic formations in hyposignal $\mathrm{T} 1$ and hypersignal $\mathrm{T} 2$, with thin walls. These cystic lesions are connected to and communicate with the intrahepatic bile ducts. He had no kidney, spleen or other abdominal abnormalities on MRI.

Liver biopsy was not performed because the procedure would bring more risks than benefits. Genetic testing has not been performed. 
Currently, the patient continues her regular clinical followup in consultation. She has no major clinical manifestations that affect her daily life. The prognosis for her illness is favorable at the moment, since the patient has no complications including no cholangitis and no signs of portal hypertension or malignancy.

Table 1: Hematological and biochemical parameters.

\begin{tabular}{|c|c|}
\hline Parameters & Results \\
\hline Hemoglobin & $12.3(\mathrm{~g} / \mathrm{dL})$ \\
\hline Hematocrit & $37,3(\%)$ \\
\hline Leukocytes & $4950(/ \mathrm{mm} 3)$ \\
\hline Platelets & $191(/ \mathrm{mm} 3)$ \\
\hline Prothrombin activity & $100(\%)$ \\
\hline C-reactive protein & $1,6(\mathrm{mg} / \mathrm{L})$ \\
\hline AST & $21(\mathrm{UI} / \mathrm{L})$ \\
\hline ALT & 12 (UI/L) \\
\hline GGT & $21(U / L)$ \\
\hline Alkaline phosphatase & $67(\mathrm{U} / \mathrm{L})$ \\
\hline Total bilirubin & $6(\mathrm{mg} / \mathrm{L})$ \\
\hline Albumin & $46.8(\mathrm{~g} / \mathrm{L})$ \\
\hline a-Fetoprotein & $1.6(\mathrm{ng} / \mathrm{mL})$ \\
\hline CEA & $3(\mathrm{ng} / \mathrm{mL})$ \\
\hline LDH & $349(\mathrm{U} / \mathrm{L})$ \\
\hline Urea & $0.35(\mathrm{~g} / \mathrm{L})$ \\
\hline Creatinine & $6(\mathrm{mg} / \mathrm{L})$ \\
\hline
\end{tabular}

AST: Aspartate aminotransferase; ALT: Alanine aminotransferase; GGT: y-glutamyl transferase; CEA: carcinoembryonic antigen

LDH: lactate dehydrogenase
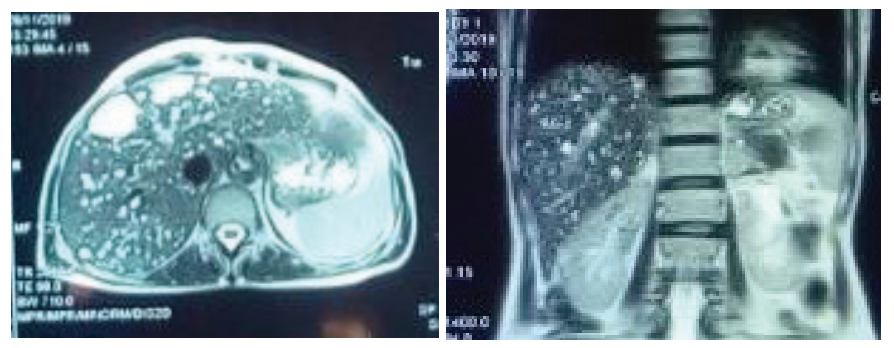

Figure 1: Magnetic resonance imaging showing ectasias of the intrahepatic bile ducts and communication with the bile branches.

\section{Discussion}

Caroli's disease is a rare autosomal recessive inherited congenital disease. Rare cases of autosomal dominant transmission have been reported [4]. Its incidence is estimated at 1 per million of the population [5]. It is associated with incomplete and defective remodeling of the embryonic ductal plate $[6,7]$. It is usually diagnosed in childhood or adolescence [4], but can be diagnosed in adulthood [8-10]. No sex predominance has been reported [11].

The clinical symptomatology of CD is not specific. Patients may be asymptomatic or have symptoms such as jaundice, right upper quadrant pain or fever [12]. Intrahepatic ductal ectasia predisposes to the stagnation of bile, which can lead to the formation of stones and predisposes to repeated cholangitis which can be complicated by serious infections such as liver abscess or septicemia [13,14]. Chronic inflammation due to gallstones in the intrahepatic ducts can lead to secondary biliary cirrhosis with its complications such as portal hypertension [14].

Liver function tests in CD may be normal or there may be reversible increases during episodes of cholangitis [15]. The level of alkaline phosphatase and direct bilirubin may be increased. The level of transaminases can be normal as it can be high and reflect a progressive hepatic fibrosis in case of Caroli syndrome [14].

The final diagnosis is confirmed by histopathology, but current non-invasive imaging tools, including Ultrasound (US), Computed Tomography (CT) and Magnetic Resonance Imaging (MRI) are considered to be the first-line diagnostic modalities [16]. The ultrasound shows saccular or spindleshaped cystic dilations predominant around the hepatic hilum without any underlying obstacle and which communicate with the rest of the biliary tree. It is a very good technique for visualizing intrahepatic lithiasis. Doppler ultrasound or multi-slice CT also enable visualization of the pathognomonic "dot sign", which represents a portal or arterial branch at the periphery of or within a pseudoseptation running through a cyst [17]. Magnetic Resonance Imaging (MRI) is a non-invasive technique that currently presents the most specific tool for diagnosing $\mathrm{CD}$. It demonstrates cystic structures of variable size which communicate freely with the biliary tree as well as the "dot sign" and intrahepatic stones [18]. Caroli syndrome differs from $\mathrm{CD}$ by the presence of smaller cystic structures $(<2 \mathrm{~cm})$ connected to the bile ducts with periportal fibrosis [19]. Significant proportion of Caroli's disease cases are transmitted in an autosomal recessive manner and are associated with autosomal recessive polycystic kidney disease [20].

The management of CD depends on the symptomatology of the patient and the extent of biliary abnormalities [10]. Cholangitis can be managed with antibiotics. In the case of cholestasis with intrahepatic lithiasis, the prescription of ursodeoxycholic acid is an option [17,21]. Surgical resection by lobectomy is recommended in case of localized disease in a lobe [22]. It reduces the risk of degeneration into cholangiocarcinoma which to be as high as 100-fold greater in patients with CD than in the general population [23]. However, in cases of diffuse disease and in case of suspected malignant transformation, liver transplantation remains the treatment of choice [24]. In case of biliary obstruction, an endoscopic sphincterotomy, radiological or surgical drainage may be applied [15].

\section{Conclusion}

Caroli disease poses a double diagnostic and therapeutic problem. The rarity of the disease, the absence of specific clinical signs and the frequent association with gallstones make diagnosis difficult. Treatment of diffuse forms is problematic and requires liver transplantation given the risk of septic complications, secondary biliary cirrhosis and degeneration. 


\section{References}

1. Pimentel F (2004) Enfermedad de Caroli. Rev Chil Cir 56: 426-433. Link: https://bit.ly/206ceqg

2. Gupta AK, Gupta A, Bhardwaj VK, Chansoria M (2006) Caroli's disease. Indian J Pediatr 73: 233-235. Link: https://bit.ly/3f9l9TZ

3. Menon S, Holt A (2019) Large-duct cholangiopathies: aetiology, diagnosis and treatment. Frontline Gastroenterol 10: 284-291. Link: https://bit.ly/3iHaF08

4. Torra R, Badenas C, Darnell A, Bru C, Escorsell A, et al. (1997) Autosoma dominant polycystic kidney disease with anticipation and Caroli's disease associated with a PKD1 mutation rapid communication. Kidney Int 52: 33-38. Link: https://bit.ly/3gB86ux

5. Bakoyiannis A, Delis S, Triantopoulou C, Dervenis C (2013) Rare cystic liver lesions: a diagnostic and managing challenge. World J Gastroenterol 19: 7603-7619. Link: https://bit.ly/3izO31s

6. Khalefa AA, Alrasheed M, Saeedan MB (2016) Central dot sign. Abdom Radiol 41: 2289-2290. Link: https://bit.ly/2Z8uTrX

7. Sato Y, Harada K, Kizawa K, Sanzen T, Furubo S, et al. (2005) Activation of the MEK5/ERK5 cascade is responsible for biliary dysgenesis in a rat model of Caroli's disease. Am J Pathol 166: 49-60. Link: https://bit.ly/302/1iP

8. Acioli LM, Gonçalves Costa LR, de Miranda Henriques MS (2014) Diffuse Caroli's disease with atypical presentation: a case report. Ann Gastroentero 27: 79-81.Link: https://bit.ly/2VXWmuf

9. Sarker I, Bhuiyan AM, Sarker MZ (2016) A middle aged man with Caroli's disease: A case report. Bangabandhu Sheikh Mujib Medical University Journal 9: 50-52. Link: https://bit.ly/3fandLn

10. Wang ZX, Li YG, Wang RL, Li YW, Li ZY, et al. (2015) Clinical classification of Caroli's disease: an analysis of 30 patients. HPB 17: 278-283. Link: https://bit.ly/3ecPxv8

11. Madjov R, Chervenkov P, Madjova V, Balev B (2005) Caroli's disease. Report of 5 cases and review of literature. Hepatogastroenterology 52: 606-609. Link: https://bit.ly/38COkML

12. Shi W, Huang XM, Feng Y, Wang FD, Gao X, et al. (2020) Factors contributing to diagnostic delay of Caroli syndrome: a single-center, retrospective study. Link: https://bit.ly/3gC4V5R
13. Cabral Correia P, Morgado B (2017) Caroli's Disease as a Cause of Chronic Epigastric Abdominal Pain: Two Case Reports and a Brief Review of the Literature. Cureus 9: e1701. Link: https://bit.ly/3eb6rKA

14. Yonem $Y$, Bayraktar $Y(2007)$ Clinical characteristics of Caroli's disease. World J Gastroenterol 13: 1930-1933. Link: https://bit.ly/3gC4qJ1

15. Padmini Y, Adhikari S, Pandit N, Awale L (2018) Caroli's disease: a diagnostic challenge. International Surgery Journal 5: 3750. Link: https://bit.ly/2Cft0R8

16. Cannella R, Giambelluca D, Diamarco M, Caruana G, Cutaia G, et al. (2020) Congenital Cystic Lesions of the Bile Ducts: Imaging-Based Diagnosis. Curr Probl Diagn Radiol 49: 285-293. Link: https://bit.ly/2ZMneia

17. Sato $Y$, Ren XS, Nakanuma $Y$ (2012) Caroli's disease: current knowledge of its biliary pathogenesis obtained from an orthologous rat model. Int $\mathrm{J}$ Hepatol 2012: 107945. Link: https://bit.ly/3gDBn81

18. Guy F, Cognet F, Dranssart M, Cercueil JP, Conciatori L, et al. (2002) Caroli's disease: magnetic resonance imaging features. Eur Radiol 12: 2730-2736. Link: https://bit.ly/3iltmjR

19. Strazzabosco M, Fabris L, Spirli C (2005) Pathophysiology of cholangiopathies. J Clin Gastroenterol 39: S90-S102. Link: https://bit.ly/3e7ETWz

20. Sato Y, Ren XS, Nakanuma Y (2012) Caroli's disease: current knowledge of its biliary pathogenesis obtained from an orthologous rat model. Int $\mathrm{J}$ Hepatol 2012: 107945. Link: https://bit.ly/2CfQKop

21. Ananthakrishnan AN, Saeian K (2007) Caroli's disease: identification and treatment strategy. Curr Gastroenterol Rep 9: 151-155. Link: https://bit.ly/2ZajV5b

22. Chen CB, Hu WD, Zhao WW, Gu YY, Hou HW, et al. (2018) Laparoscopic hepatectomy for the treatment of Caroli's disease: a case report. Ann Surg Treat Res 94: 162-165. Link: https://bit.ly/2VZDE5H

23. Jang MH, Lee YJ, Kim H (2014) Intrahepatic cholangiocarcinoma arising in Caroli's disease. Clin Mol Hepatol 20: 402-405. Link: https://bit.ly/3iNwD1J

24. DeKerckhove L, De Meyer M, Verbaandert C, Mourad M, Sokal E, et al. (2006) The place of liver transplantation in Caroli's disease and syndrome. Transpl Int 19: 381-388. Link: https://bit.ly/2ZOTIs4

Discover a bigger Impact and Visibility of your article publication with

\section{Peertechz Publications}

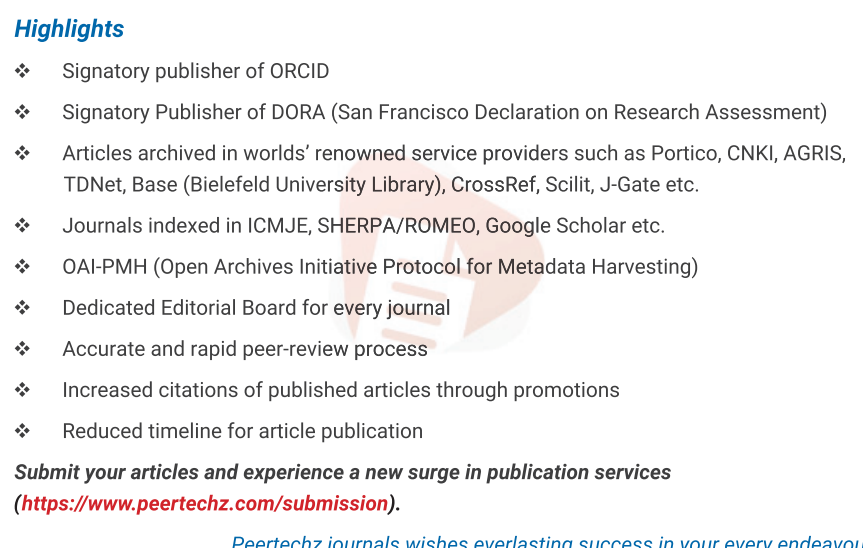

Peertechz journals wishes everlasting success in your every endeavours.

Copyright: ๑ 2020 Lemfadli Y, et al. This is an open-access article distributed under the terms of the Creative Commons Attribution License, which permits unrestricted use distribution, and reproduction in any medium, provided the original author and source are credited. 